\title{
Temporal and spatial variations of biodeposits - a preliminary investigation of the role of fecal pellets in the Sylt-Rømø tidal area
}

\author{
Ingrid Austen \\ GKSS Forschungszentrum GmbH, Institute of Hydrophysics; Max-Planck-Straße, \\ D-21502 Geesthacht, Germany
}

\begin{abstract}
The fecal pellets of Heteromastus filiformis and Hydrobia ulvae are abundant on the sediment surface of the Sylt-Rømø tidal flats. Although Cerastoderma edule is present in most parts of the study area, only small amounts of its pellets could be found. Fecal pellets are non-randomly distributed in the study area. Large amounts of $H$. ulvae pellets are found in the mud flats and smaller amounts in the mixed flats and sand flats, where $H$. filiformis pellets predominate as biogenic component. This distribution pattern varies with time under the influence of environmental factors. Marked temperature fluctuations provide seasonal signals reflecting distinct patterns. The results show a net balance of biodeposit components in the sediment. This could be a result of the sheltered location of the area and this fits in well with the mostly stable sedimentological picture.
\end{abstract}

\section{INTRODUCTION}

It is a well established fact that the tidal flat sediments are strongly influenced by organisms (Wohlenberg, 1937; Verwey 1952; Reineck, 1988). For example, Thiel et al. (1984) classify the major forms of biological activity in the Büsumer Watt in the south eastern North Sea as follows: bioturbation, bioresuspension, biostabilisation and biodeposition. Biodeposition of particles plays an important role in sedimentation (cf. Verwey, 1952; Haven \& Morales-Alamo, 1972; Cadée, 1979; Gast et al., 1984; Dittmann, 1987). Filter feeders as well as deposit feeders collect fine-grained material, i.e. silt and clay particles incorporating organic material. The undigested components of the diet are compacted in the gut and ejected as fecal pellets. The process of fecal pellet production is called biodeposition (cf. Haven \& Morales-Alamo, 1966).

Fecal pellets have faster sinking rates than their constituent particles (Haven \& Morales-Alamo, 1972; McCall, 1979). As a result, they settle in areas where hydrodynamic conditions would otherwise generally prevent the sedimentation of fine-grained material (Schwarz, 1932; Haven \& Morales-Alamo, 1968; Rhoads, 1974).

The present study is concerned with the temporal and spatial variation of fecal pellets on the sediment surface and represents a preliminary attempt at semi-quantitatively assessing the role of fecal pellets in the Sylt-Rømø tidal flats. It forms part of the SWAP ecosystem research project on exchange processes between the north German Wadden Sea and the North Sea. 


\section{STUDY AREA}

The Sylt-Rømø tidal basin is situated in the northern part of the German Wadden Sea (Fig 1). This embayment is located between the islands Sylt and Rømø which are both connected to the German and Danish mainland by causeways. The exchange of water masses is restricted to the "Lister Tief", a tidal inlet between Sylt and Rømø. The mean tidal range varies between $1.5 \mathrm{~m}$ in the northern part and $1.7 \mathrm{~m}$ in the southern part (Bundesanstalt für Seeschiffahrt und Hydrographie). Salinity ranges between 28-32\%o (Pfaffenhöfer, 1978).

The Königshafen is a tidal embayment to the north of the island of Sylt which is almost completely separated from the remainder of the Sylt-Rømø tidal basin.

The sediment distribution pattern in the Sylt-Rømø tidal area is dominated by sand flats ( $<10 \%$ mud by weight), with a typical decrease in mean grain size towards high water level (Bayerl, 1992). In Königshafen the sediment is characterized by medium sand

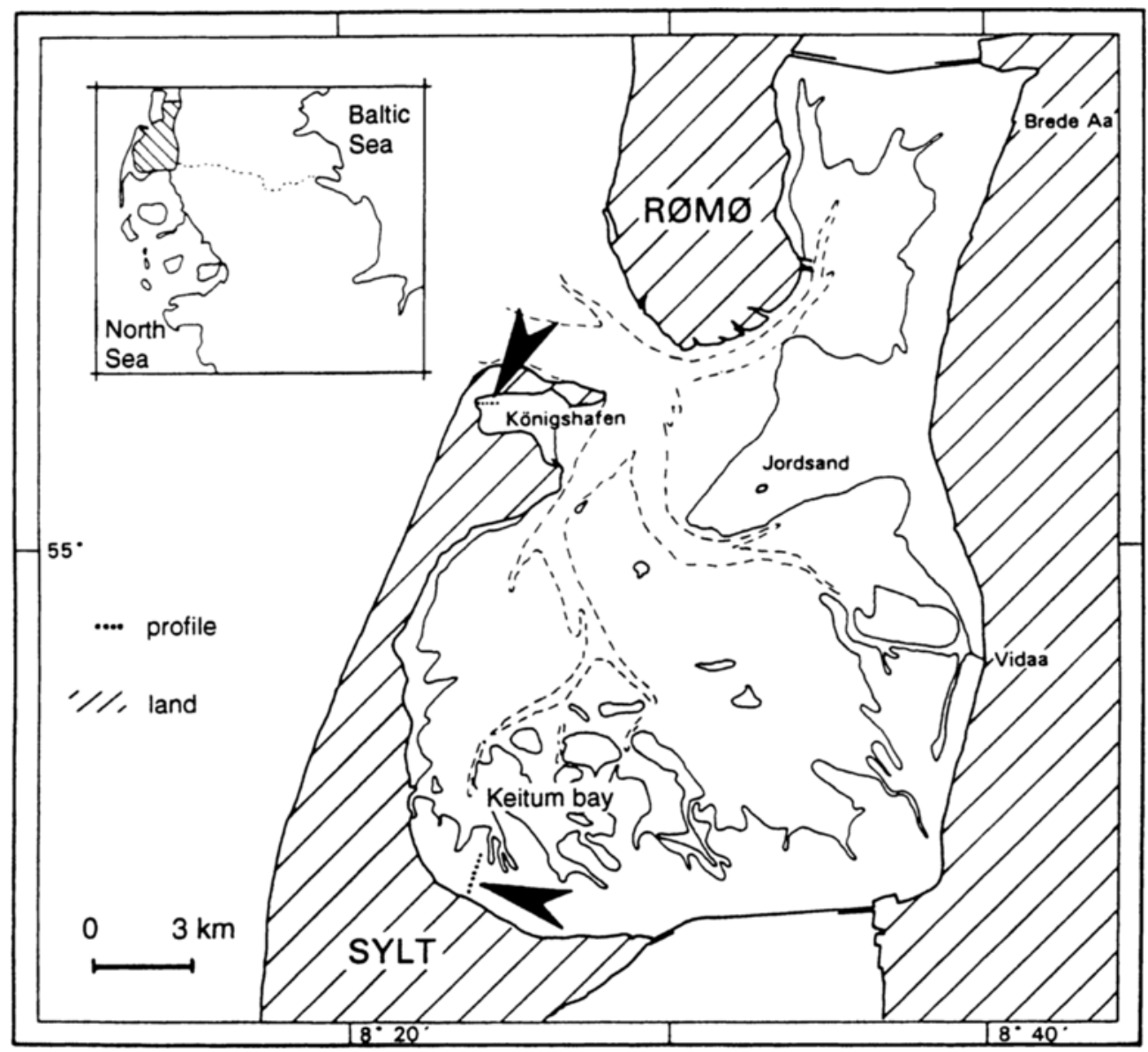

Fig. 1. Map of the Sylt-Rømø tidal area with mean low-tide line. Profiles indicated by arrows 
and only small areas of mud flats (> $50 \%$ mud by weight) and sandy mud flats (10-50\% mud by weight) are to be found in the western part of the bay (Austen, 1992, 1994).

The present study concerning the distribution of fecal pellets at the sediment surface was undertaken on an E-W profile in Königshafen, and a NNE-SSW profile in the inner part of Keitum Bay (Fig 1). It was carried out from October 1991 to March 1994.

\section{METHODS}

The profile in Keitum Bay had 13 permanently marked sampling stations at intervals of $100 \mathrm{~m}$; the transect in Königshafen had 14 stations at intervals of $50 \mathrm{~m}$. The main sediment types of the study area are represented along these profiles. Every quarter year 3 samples of the uppermost $0.5 \mathrm{~cm}$ of sediment were taken at each position. Species of fecal pellets were determined under the microscope according to the classification scheme of Austen (1995). Their volumes were estimated (Terry \& Chilinger, 1955) and expressed as a proportion of the wet sediment volume $\left(2.5 \mathrm{~cm}^{3}\right)$ whereby the term "relative fecal pellet volume" is used. Each value represents the mean of 3 samples.

Additional sediment cores, $20 \mathrm{~cm}$ in length and $6.9 \mathrm{~cm}$ in diameter, were taken. The material was sieved (at $1 \mathrm{~mm}$ mesh size) to obtain the macrozoobenthos (Ankar et al., 1979). Large species such as Heteromastus filiformis and Cerastoderma edule were counted in situ.

Sediment cores were also taken to determine the relative fecal pellet volume with depth. These cores were vertically divided into 2 parts. One part was used to describe the lithogenous characteristics and from the other part horizontal samples were taken in cm-steps and analysed in the same way as the surface samples.

Mud contents (weight-\% of size fraction $<63 \mu \mathrm{m}$ ) of the surficial sediments were determined by wet sieving the samples after a standardized pretreatment (Bayerl, 1992). According to Figge et al. (1980), the following classification of sediment types was applied: sand flat (<10\% mud by weight); mixed flat ( $10-50 \%$ mud by weight) and mud flat (>50\% mud by weight).

\section{RESULTS}

In both study areas the most abundant fecal pellets in the surficial sediment were those of Heteromastus filiformis and Hydrobia ulvae. Only small amounts of feces of Cerastoderma edule, Macoma baltica and Mytilus edulis were found, even though large numbers of these species are present.

Densities of $H$. filiformis and $H$. ulvae and species-specific relative fecal volumes show similar trends along the profiles. During the whole study period the feces were found at the surface concurrently with the organisms. As an example the situation for March 1993 at the Königshafen transect is given in Figure 2. The whole data set is presented in Tables 1-4.

Along the Königshafen profile the major macrozoobenthos species show distinct distribution patterns. The small gastropod $H$. ulvae dominates at the mud flat stations. On the other hand, the polychaete $H$. filiformis prevails at the mixed and sand flat stations. This results in a spatial differentiation of fecal pellets (Fig. 2 ).

The spatial distribution of macrozoobenthos along the profile in Keitum Bay (Table 4) shows small differences from the situation in Königshafen (Table 3). H. filifor- 

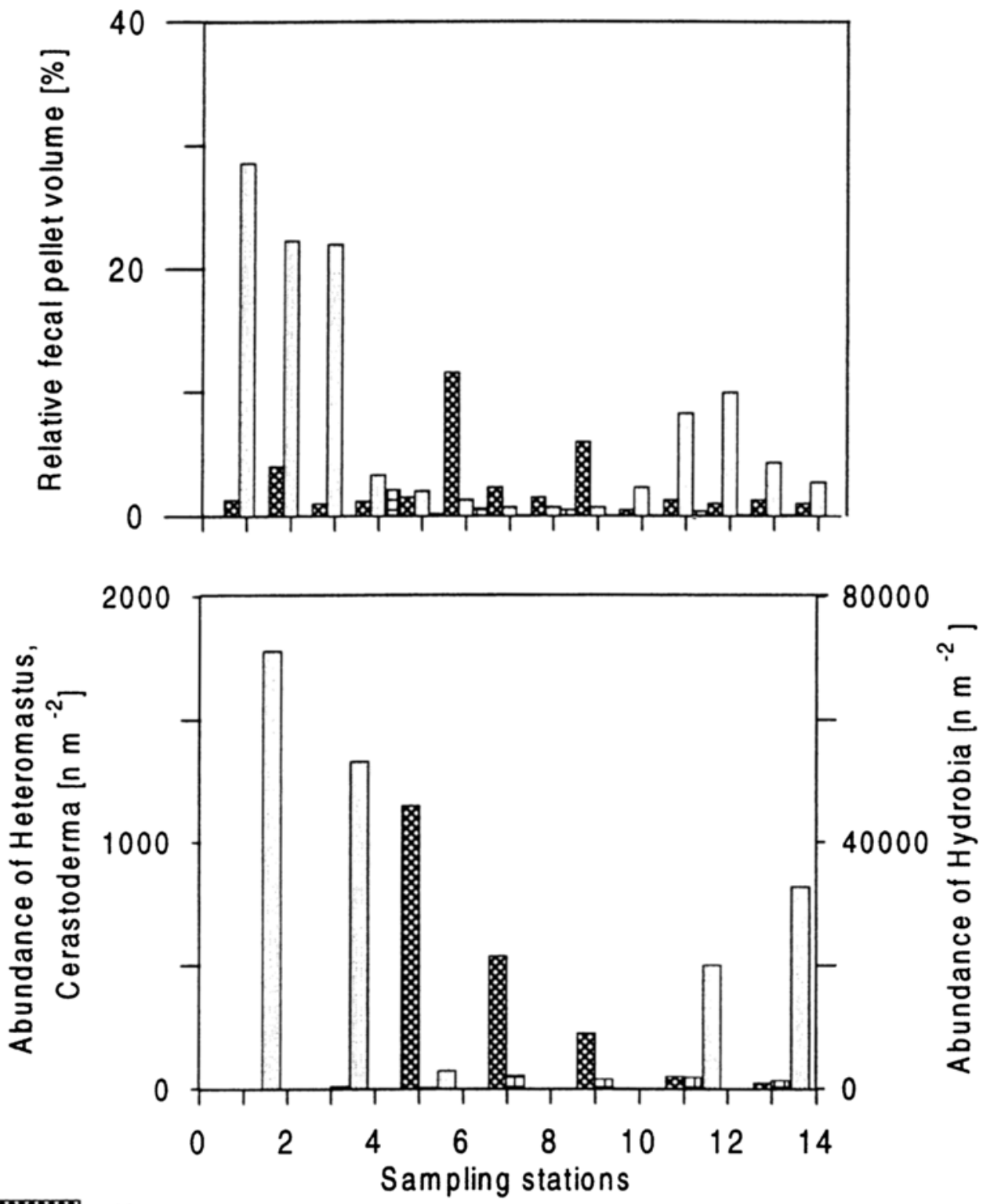

Heteromastus

Hydrobia

\section{\#曲曲 Cerstoderma}

Fig. 2. Relationship between volume of fecal pellets and abundance of macrobenthos for the profile in Königshafen in March 1993 


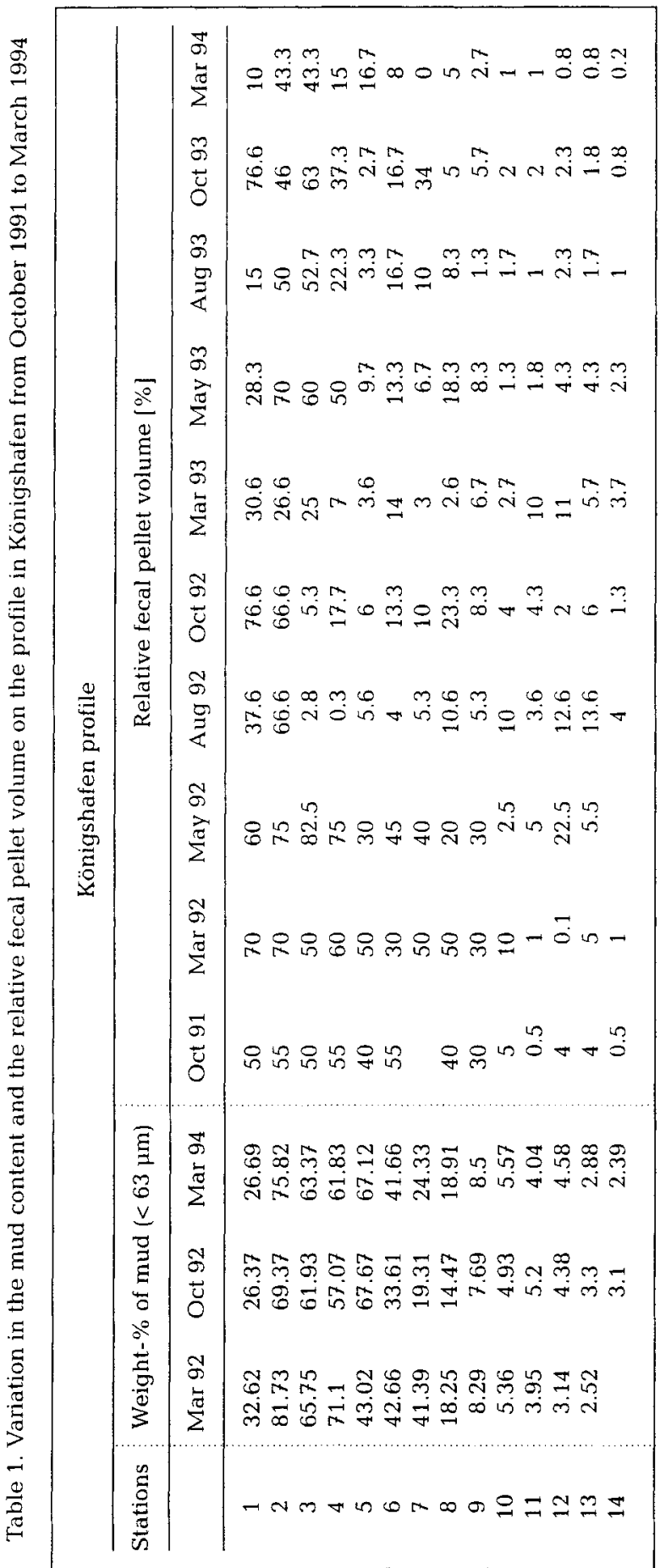




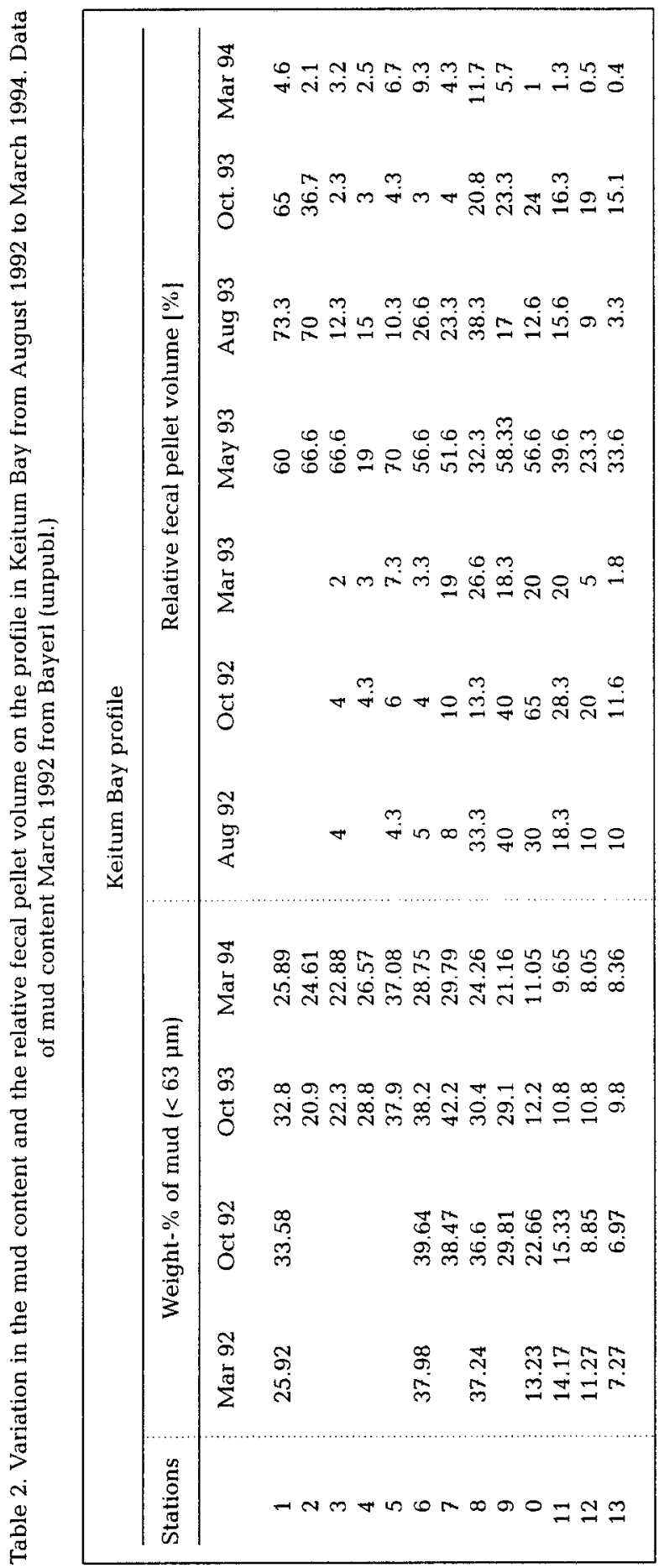


Biodeposits - the role of fecal pellets

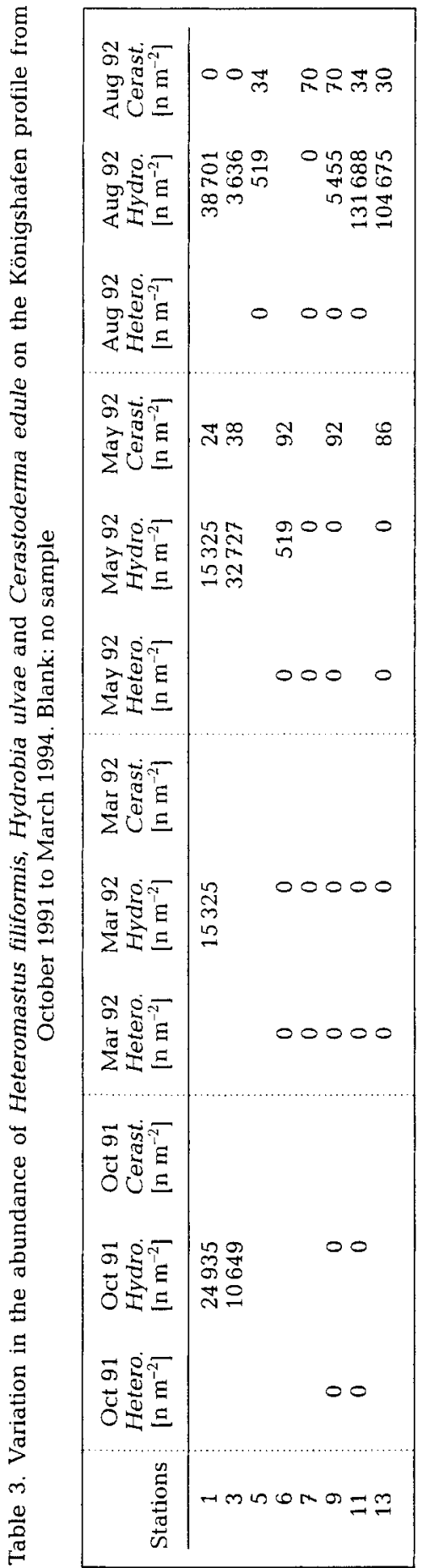

\begin{tabular}{|c|c|c|c|}
\hline 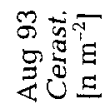 & 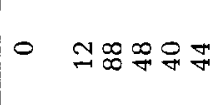 & & \\
\hline 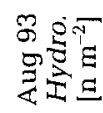 & $\begin{array}{l}\stackrel{g}{g}, 00000 \\
\text { N } \\
\infty \stackrel{N}{\infty}\end{array}$ & & \\
\hline 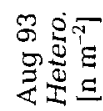 & - og: & & \\
\hline 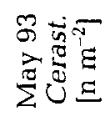 & 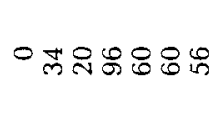 & & \\
\hline 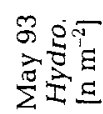 & 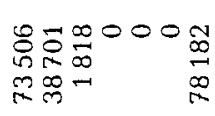 & & \\
\hline 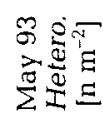 & ooom & & \\
\hline 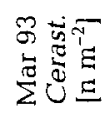 & ○ণ & 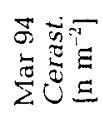 & ON⿴ \\
\hline 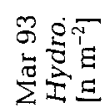 & 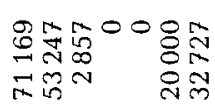 & 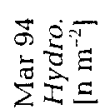 & 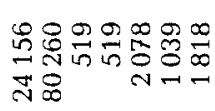 \\
\hline 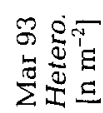 & 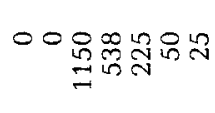 & 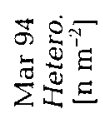 & ం ం 유 \\
\hline 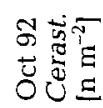 & 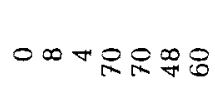 & 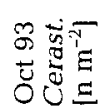 & 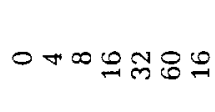 \\
\hline 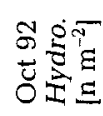 & 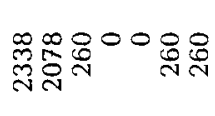 & 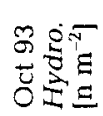 & 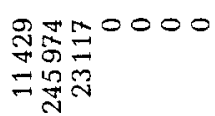 \\
\hline 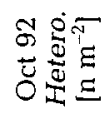 & 0000 & 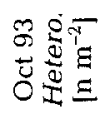 & 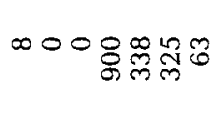 \\
\hline$\frac{n}{0}$ & $-\sin \theta=m$ & 总 & $-\infty \cos \sigma=m$ \\
\hline
\end{tabular}




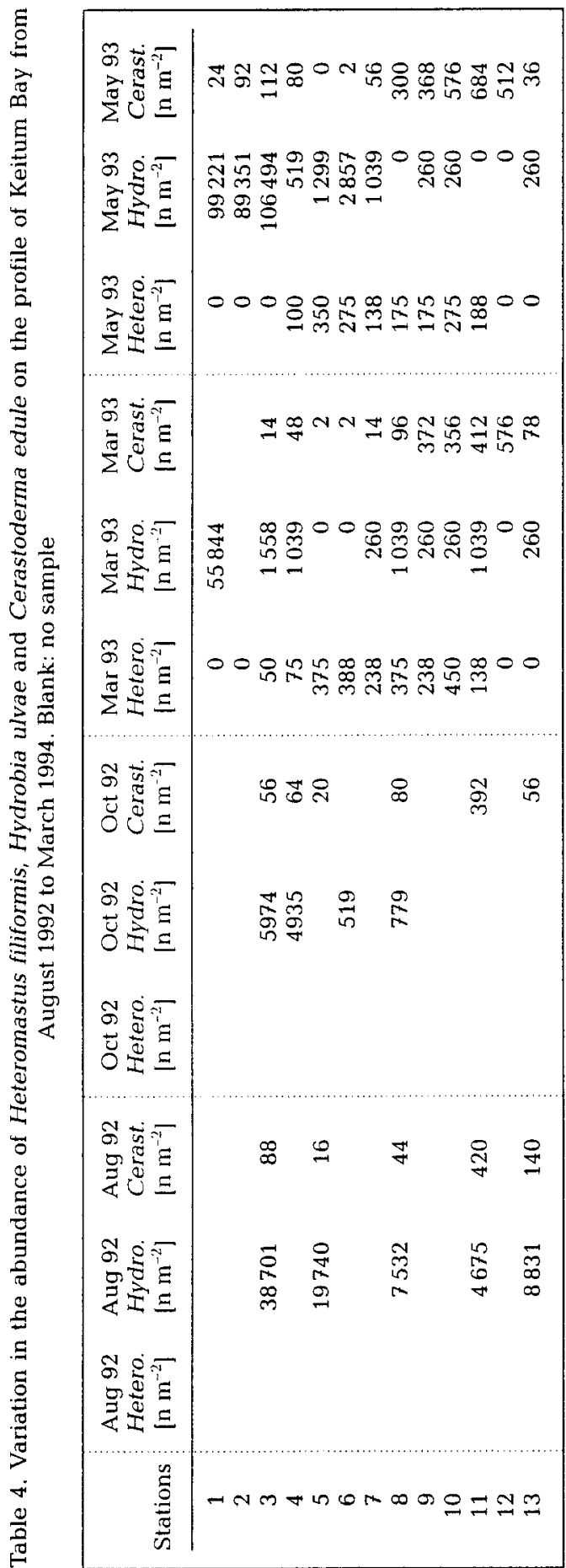

\begin{tabular}{|c|c|}
\hline 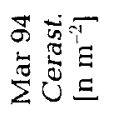 & 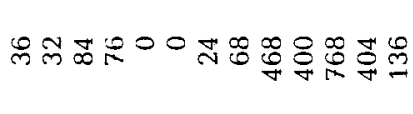 \\
\hline 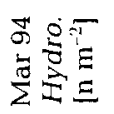 & 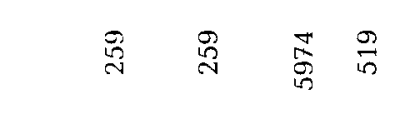 \\
\hline 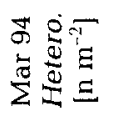 & 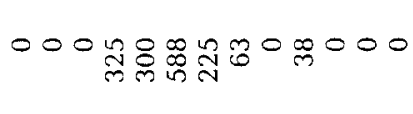 \\
\hline 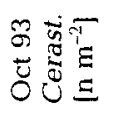 & 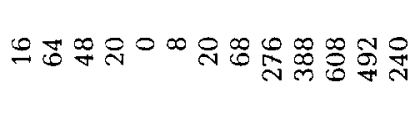 \\
\hline 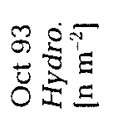 & 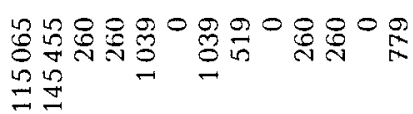 \\
\hline 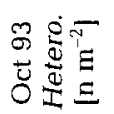 & oоm \\
\hline 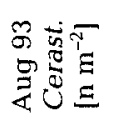 & 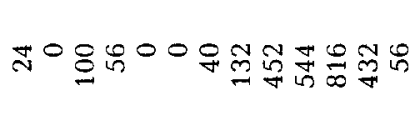 \\
\hline 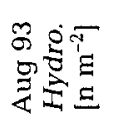 & 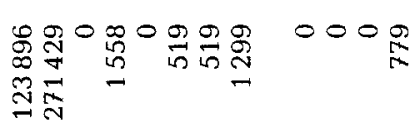 \\
\hline 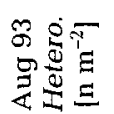 & $000 m 00 n 00 \%$ M \\
\hline 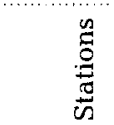 & rNm \\
\hline
\end{tabular}


mis dominates on the mixed flat in the central part of the profile. $H$. ulvae reaches high abundances further ashore where $H$. filiformis is not present. Along the profile in Keitum Bay more feces of $C$. edule and $H$. ulvae are present. Similarly species abundances are higher, especially a number of small $H$. ulvae (length $<1 \mathrm{~mm}$ ) in the northeastern section of the Keitum Bay profile (site 11-13).

Mud contents and amounts of pellets show similar trends along both profiles (Tables $1,2)$. On the profile in Königshafen up to $80 \%$ of the sediment volume of the mud flats is made up of fecal pellets. At the mixed flats the relative volume of fecal pellets on the sediment surface decrease to values ranging from 50 to $1 \%$. The coarser grain in the sand flats is accompanied by a decrease in the relative fecal pellet volume showing a range from 13-1 \%. The situation on Königshafen profile in March 1992 is given in Figure 3.

A decrease in the relative fecal pellet volume coinciding with a decrease in the mud content of the surface sediment is also found at the stations in Keitum Bay. In this area mud flats are not present. Relative fecal pellet volumes of up to $70 \%$ are indicative of mixed flats, except at the sites 3 to 7 where the relative fecal pellet volume in mixed flat areas decreases to values ranging from 50-5\%. At the sand flat positions (sites 11-13) the relative fecal pellet volume decreases and values range from 20-1\% (Table 2).
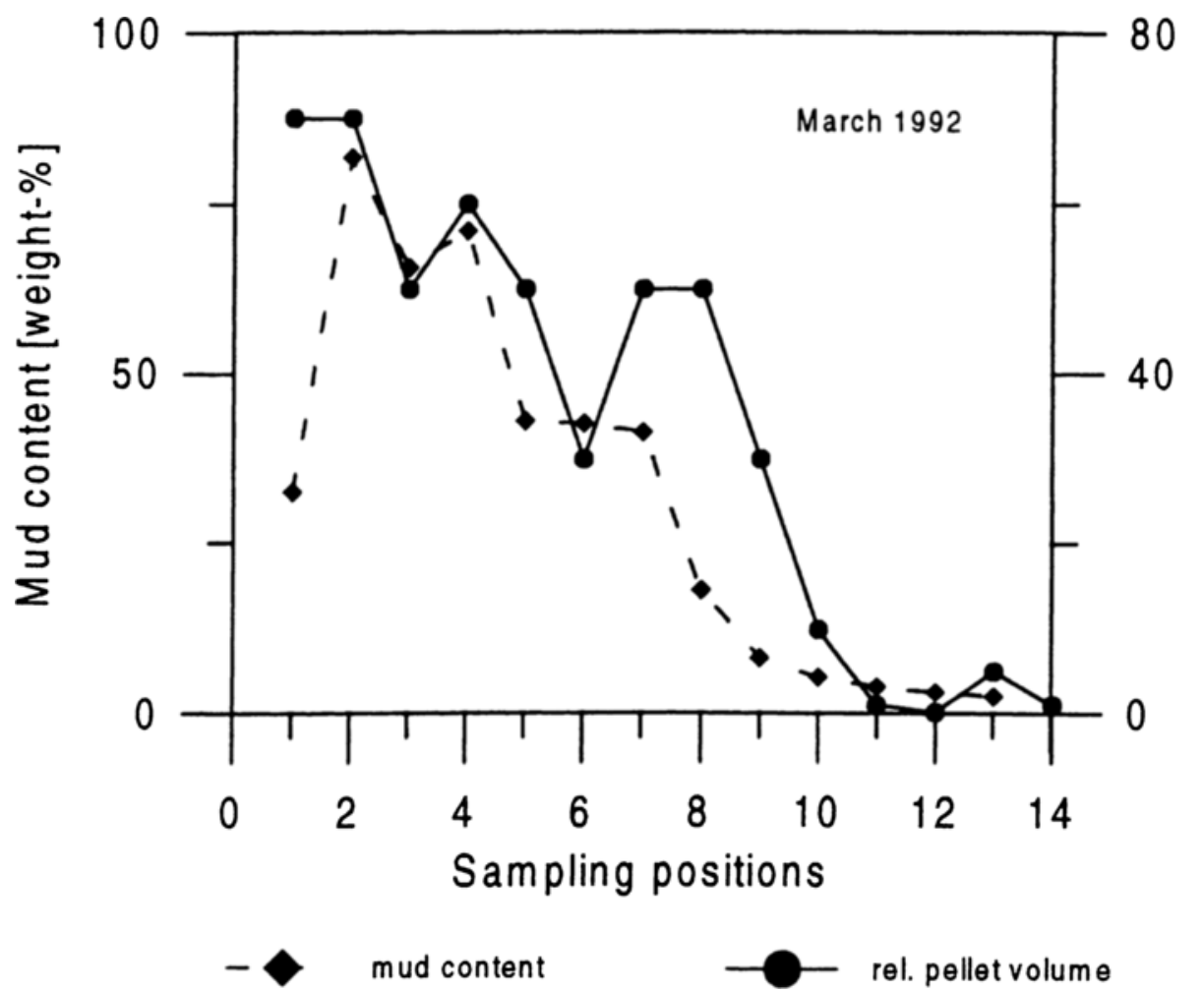

Fig. 3. Relationship between relative fecal pellet volume and mud content on the profile in Königshafen. Situation March 1992 
Relative volumes of fecal pellets varied seasonally in both study areas (Tables 1,2). For example at the profile in Königshafen, the central stations (sites 5-9) had relatively large amounts of fecal pellet volumes ranging from 55 to $20 \%$ at the beginning of the study period in October 1991 until May 1992. A decrease was observed in August 1992 to values of 5 to $10 \%$ and, in the following sampling periods, these sites were likewise characterized by small fecal volumes, except for the site 7 in October 1993 where the fecal pellet volume increased to $34 \%$. Looking at the complete profile the amount of pellets was generally reduced in spring 1993 and 1994 in comparison to the other sampling seasons.

The seasonal variations at the Keitum Bay profile differ in some cases from the development in Königshafen. In Keitum a reduced volume of fecal pellet content was only found in March 1994 with values between 10 and $0.5 \%$, while in March 1993 the values of pellet content reached a maximum of $26 \%$ at site 8 . On the other hand, the situation in May 1993 was characterized by large pellet volumes at all sites (66-23\%). In Königshafen no obvious increase of pellet content was observed during this period.

The relative volume of fecal pellets generally decreased with the depth (Fig. 4). Homogeneous mud developed at depths $>5 \mathrm{~cm}$, whereas a compacted mud layer ("clay") appeared at depths from 7 to $17 \mathrm{~cm}$. This material was usually free of fecal pellets. A few exceptions to this general pattern were observed; for example at Kö 8 a mud layer containing feces was observed at a depth of $17 \mathrm{~cm}$.

\section{DISCUSSION}

The results of the investigations of the temporal and spatial distribution patterns of fecal pellets in the surficial sediments in the Sylt-Rømø tidal area suggest that the biodeposits are mostly autochthonous. This interpretation is based on the positive relationship between animal abundance and fecal pellet volume. In addition, a high amount of pellets is found in the mud flats but not in the sand flats.

An exception to the positive relationship between mud content and number of pellets was found on the profile of Keitum Bay (sites 3-7), where a mixed flat has developed in the vicinity of a Mytilus edulis bed. In this area, only a very small amount of Mytilus pellets was found on the sediment surface. The fast filtration of $M$. edulis (Verwey, 1952) and the subsequent production of feces and pseudofeces cause this accumulation of fine material. As a result of the low stability of the Mytilus feces, only small amounts can be identified in the sediment. The same situation was found by Brinke et al. (1995) in the Oosterschelde (Dutch Wadden Sea).

The large-scale distribution pattern of fecal pellets in the Sylt-Rømø tidal area shows distinct variation with time, which may be linked to a variety of factors. One of the most important being temperature. A marked drop in temperature is a seasonal signal that reflects pellet distribution patterns. There was a decrease in the volume of biodeposits at all stations after 14 days of ice cover in March 1994, which may be explained by physical disturbance. It is possible that the surface layer and, within it, the fecal pellets are removed by ice floes. In addition, a reduced production of fecal pellets at low temperatures (Kautsky \& Evans, 1987) is consistent with the paucity of pellets in winter.

Other factors which cause fluctuations in pellet distribution are food concentration and sediment load which affect the feeding activity and, consequently, pellet production 

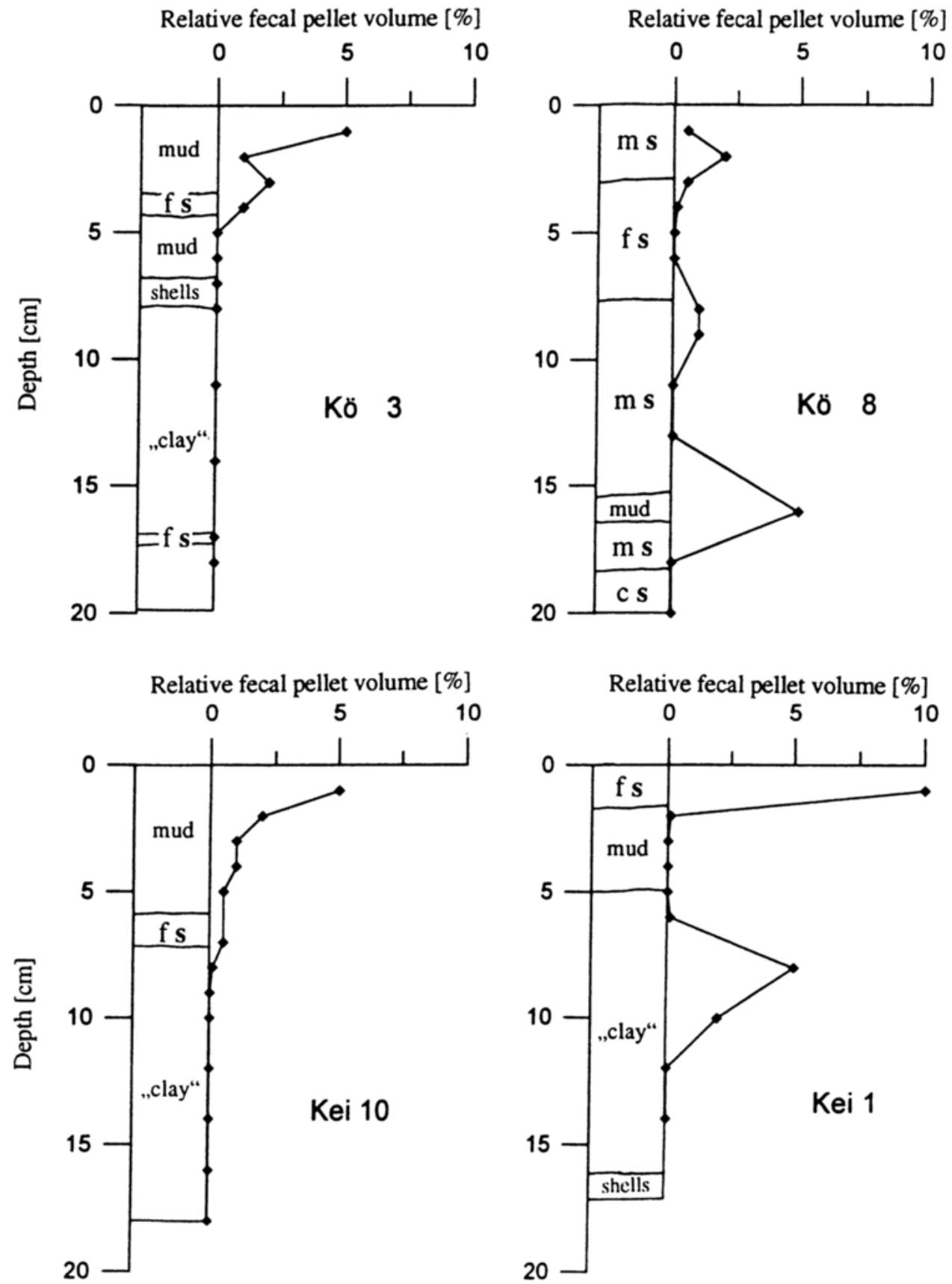

(10

10

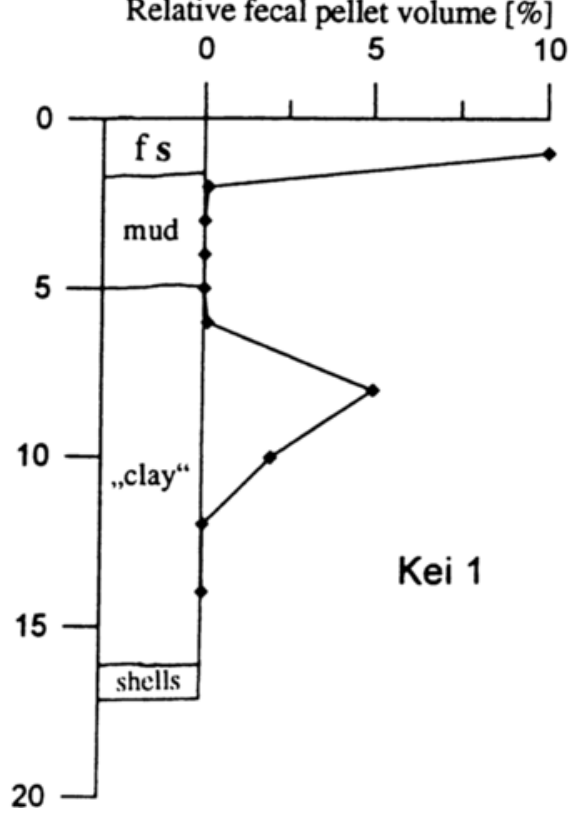

Fig. 4. Variation in the relative fecal pellet volume with depth at two positions on the profile in Königshafen and two positions on the profile in Keitum Bay. Mud $(<63 \mu \mathrm{m})$, fs = fine sand $(63-125 \mu \mathrm{m}), \mathrm{ms}=$ medium sand $(125-250 \mu \mathrm{m}), \mathrm{cs}=$ coarse sand $(>250 \mu \mathrm{m})$, "clay" = very compact 
(Tsuchiya, 1980); population dynamics, spawning cycles and predatory pressure further influence the amount of fecal pellets produced (Cadè, 1979; Tsuchiya, 1980; Thiel et al., 1984). In addition to large-scale fluctuations, small-scale variations in pellet distribution also occur. Biodeposits were not regularly distributed at the surface but concentrated, for example, in ripple troughs (Pryor, 1975).

Current velocity and wave action are other important factors that influence the distribution patterns of fecal pellets. A certain stability of pellets is required to resist these forces during transport. Other factors which cause destruction of pellets are the feeding activity of meio- and microbenthos (Muñoz, 1992) as well as compaction resulting from the overlying sediment. These factors lead to a decrease in the number of pellets with sediment depth (Muñoz, 1992; Rhoads, 1967, 1974; Plath, 1965) and finally the development of homogeneous mud (Führböter, 1988). However, the fact that a compacted mud layer ("clay"), free of pellets, appears at 7-17 cm depth does not indicate that the enrichment of fine-grained material in deeper sediment layers results from disintegrated pellets.

The results show that sediment is not net accumulated by the biota. While fecal pellets play an important role in the composition of surficial sediments of the Sylt-Rømø tidal area, only very small areas south of the Rømø dam exist, where also deeper sediment layers contain feces (Bayerl, pers. comm.). This suggests that the study area is generally characterized by a balanced budget of pellets without large-scale, long-term net enrichment or net loss of biodeposits.

\section{CONCLUSION}

An evaluation of the total amount of fine-grained material concentrated in the fecal pellets is currently not possible because of insufficient data. The balanced volume of biodeposits in Sylt-Rømø tidal bay, whereby accumulation is counterbalanced by erosion, can be explained by the sheltered location of the site. Dams connect the islands Sylt and Rømø to the mainland and create a tidal bay with only one inlet, the Lister Tief. As a result, most parts of the area are protected from wave action from the open North Sea. Consequently, the sedimentological picture seems to be stable in the long-term with only a few indications of net sediment accumulation or net erosion. Bayerl (1992) found a typical lithogenous mud layer in parts of inner Keitum Bay which is dated 3000 years B.P. at $1 \mathrm{~m}$ below mean sea-level. This suggests a slow sedimentation rate. In some parts of the Sylt-Rømø tidal area the outcrop of this layer indicates erosion. Evidence of a net balance in biodeposition is consistent with the sediment distribution pattern.

In other regions of the world, biodeposition can lead to a net accumulation of fine material. For the North Friesian tidal flats, Plath (1965) postulates a net accumulation of fecal pellets in the vicinity of brushwood groynes. Net accumulation has also been reported for some estuaries (Haven \& Morales-Alamo, 1972) and interdeltaic areas (Pryor, 1975). The sediment of the large transgressive inland basin Mutsu Bay (Japan) is mostly covered with pellets (Minoura \& Osaka, 1992). Also in the Bjørnafjorden (Norway) fecal pellets make up the bulk of the sediment (Gonzáles et al., 1994). All these regions of net accumulation of biodeposits stand in contrast to the Sylt-Rømø tidal flats, where there appears to be a net balance in biodeposition. The biological significance of these contrasting trends remains to be investigated. 
Acknowledgements. This study was supported by the Federal Ministry of Education, Science, Research and Technology (BMBF) as part of the "Ecosystem Research of the Schleswig-Holstein Wadden Sea" (project-no. 03F0006D). The project was co-ordinated by the Regional Office of the National Park Schleswig-Holstein Wadden Sea. I thank Prof. Köster for supervising the study and providing helpful comments. Many thanks are also due to the entire "Küstengeologie" team who provided stimulating ideas and valuable help, especially to Dr. Runte and Dr. Milkert, and two unknown referees for helpful criticism. Furthermore, I wish to thank all persons involved in the SWAPProgramme for their co-operation, exchange of ideas and discussion of results. This is publication no. 271 of the project "Ecosystem Research Wadden Sea".

\section{LITERATURE CITED}

Ankar, S., Andersin, A.-B., Lassing, J., Norling, L. \& Sandler, H., 1979. Methods for studying benthic macrofauna. An intercalibration between two laboratories in the Baltic Sea. - Finn. mar. Res. 246, $147-160$.

Austen, I., 1992. Geologisch-sedimentologische Kartierung des Königshafens (List/Sylt). - Meyniana $44,45-52$.

Austen, I., 1994. The surficial sediments of Königshafen - variations over the past 50 years. - Helgoländer Meeresunters. 48, 163-171.

Austen, I., 1995. Die Bedeutung der Fecal Pellets mariner Invertebraten für den Sedimenthaushalt im Sylt-Rømø Watt. - Ber. Forsch. Technol. Zentr. Westküste Univ. Kiel 7, 1-107.

Bayerl, K., 1992. Zur jahreszeitlichen Variabilität der Oberflächensedimente im Sylter Watt nördlich des Hindenburgdammes, - Ber. Forsch. Technol. Zentr. Westküste Univ. Kiel 2, 1-134.

Cadée, G.C. 1979. Sediment reworking by the polychaete Heteromastus filiformis on a tidal flat in the Dutch Wadden Sea. - Neth. J. Sea Res. 13, 441-456.

Dittmann, S., 1987. Die Bedeutung der Biodeposite für die Benthosgemeinschaft der Wattsedimente. Unter besonderer Berücksichtigung der Miesmuschel Mytilus edulis L. Diss., Univ. Göttingen, $182 \mathrm{pp}$.

Figge, K., Köster, R., Thiel, H. \& Wieland, P., 1980. Schlickuntersuchungen im Wattenmeer der Deutschen Bucht. - Küste, 35, 187-204.

Führböter, A., 1988. Sedimentpetrographie. Teil 2: Sedimente und Sedimentgesteine. Schweizerbart, Stuttgart, 1-1141.

Gast, R., Köster, R. \& Runte, K., 1984. Die Wattsedimente der nördlichen und mittleren Meldorfer Bucht. Untersuchungen zur Frage der Sedimentverteilung und der Schlicksedimentation. Küste 40,165-257.

González, H. E., González, S. R. \& Brummer G.-J. A., 1994. Short-term sedimentation pattern of zooplankton, faeces and microplankton at a permanent station in the Bjørnafjorden (Norway) during April-May 1992. - Mar. Ecol. Prog. Ser. 105, 31-45.

Haven, D.S. \& Morales-Alamo, R., 1966. Aspects of biodeposition by oysters and other invertebrate filter feeders . - Limnol. Oceanogr. 11, 487-498.

Haven, D.S. \& Morales-Alamo, R., 1968. Occurrence and transport of faecal pellets in suspension in a tidal estuary. - Sediment. Geol. 2, 141-151.

Haven, D.S. \& Morales-Alamo, R., 1972. Biodeposition as a factor in sedimentation of fine suspended solids in estuaries. - Mem. geol. Soc. Am. 133, 121-130.

Kautsky, N. \& Evans, S., 1987. Role of biodeposition by Mytilus edulis in the circulation of matter and nutrients in a Baltic coastal ecosystem. - Mar. Ecol. Prog. Ser. 38, 201-212.

McCall, P. L., 1979. The effects of deposit feeding oligochaetes on particle size and settling velocity of Lake Erie sediments. - J. sedim. Petrol. 49, 813-818.

Minoura, K. \& Osaka, Y., 1992. Sediments and sedimentary processes in Mutsu Bay, Japan: Pelletization as the most important mode in depositing argillaceous sediments. - Mar. Geol. 103, 359-365.

Muñoz, C. N., 1992. Benthic fecal pellets. Cycling of sediment and organic carbon by Heteromastus filiformis. Diss., Univ. Oldenburg, $156 \mathrm{pp}$.

Pfaffenhöfer, G.-A., 1978. Concentrations of particulate matter in the North FrisianWadden Sea. Helgoländer wiss. Meeresunters. 31, 367-379. 
Plath, M., 1965. Ein im Gezeitenbereich des Wattenmeeres selbsttätig arbeitendes Sinkstoff-Schöpfgerät und die Bedeutung der Wattfauna für die Bildung von Sinkstoffen. - Küste 13, 119-132.

Pryor, W.A., 1975. Biogenic sedimentation and alteration of argillaceous sediments in shallow marine environments. - Bull. Geol. Soc. Am. 86, 1244-1254.

Reineck, H. E., 1988. Das Watt, Ablagerungs-und Lebensraum. Kramer, Frankfurt a. M., 51-62.

Rhoads, D. C., 1967. Biogenic reworking of intertidal and subtidal sediments in Barnstable Harbor and Buzzards Bay, Massachusetts. - J. Geol. 75, 461-476.

Rhoads, D. C., 1974. Organism-sediment relations on the muddy sea floor. - Oceanogr. mar. Biol. 12, 263-300.

Schwarz, A, 1932. Der tierische Einfluß auf die Meeressedimente - besonders auf die Beziehung zwischen Verfrachtung, Ablagerung und Zusammensetzung von Wattsedimenten. - Senkenbergiana 14, 118-159.

Ten Brinke, W. B. M., Augustinus, P. G. E. F. \& Berger, G. W., 1995. Fine-grained sediment deposition on mussel beds in the Oosterschelde (The Netherlands), determined from echosoundings, radio-isotopes and biodeposition field experiments. - Estuar. coast. Shelf Sci. 40, 195-217.

Terry, R. D. \& Chilinger, G. V., 1955. Comparison charts for visual estimation of percentage composition. - J. sedim. Petrol. 25, 229-234.

Thiel, H., Grossmann, M. \& Spychaller, H., 1984. Quantitative Erhebungen über die Makrofauna in einem Testfeld im Büsumer Watt und Abschätzung ihrer Auswirkung auf den Sedimentverband. - Küste 40, 259-314.

Tsuchiya, M., 1980. Biodeposit production by the mussel Mytilus edulis L. on rocky shores. - J. exp. mar. Biol. Ecol. 47, 203-222.

Verwey, J., 1952. On the ecology of distribution of cockle and mussel in the Dutch Wadden Sea, their role in sedimentation and source of their food supply. - Archs néerl. Zool. 10, 172-239.

Wohlenberg, E., 1937. Die Wattenmeerlebensgemeinschaft im Königshafen von Sylt. - Helgoländer wiss. Meeresunters. 1, 1-92. 